\title{
Spatial Distribution of Investment Incentives and the Impact of New Incentive System for Less Developed Regions in Turkey ${ }^{1}$
}

\section{Onur SUNGUR ${ }^{2}$}

\begin{abstract}
Regional policy has been on the agenda of Turkey since the First Five-Year Development Plan (1963-1967), and so far, Turkey has put into practice to overcome regional disparities, one of the most important is regional-sectoral incentives. Thus, the incentive system, which has undergone many changes until today, has been revised and updated in 2012. Although this incentive system has been put into practice for increasing the investment in eastern provinces/regions, development gap between eastern and western regions still stands. The main purpose of this study is to investigate the success of the new incentive system and to determine whether the new investment incentive system is effective in shifting investments from developed regions to backward regions in Turkey. In the study, the regional distribution of investment incentives during 2001-2016 and the effect of new investment incentive system to change the distribution of investments in favor of less developed provinces/regions will be examined. By using investment incentives data, regional distribution of investments will be revealed with the help of map-graph technique. The study found that both the share of incentive certificates and the share of the investment amount have increased during the period of 2001-2016 in the less developed provinces. From this point of view, it is possible to say that the new investment incentive system has a positive impact on increasing the share of incentives in these provinces.
\end{abstract}

Key words: Regional Development, Regional Disparities, Investment, Incentives

JEL Classification: R11, R12, R58

Received: 30 July 2018/Accepted: 25 February 2019 / Sent for Publication: 18 March 2019

\section{Introduction}

Regional development has been a major concern for both policymakers and scholars from various disciplines since it has always been difficult to define a single remedy for

\footnotetext{
${ }^{1}$ The earlier version of this paper was presented (not published) at the Anadolu International Conference in Economics (EconAnadolu), 11-13 May 2017, Eskişehir, Turkey

${ }^{2}$ Assoc.Prof.Dr.; Burdur Mehmet Akif Ersoy University, Department of Economics, Burdur, Turkey, email: onursungur@mehmetakif.edu.tr
}

(C) 2019 by the authors; licensee Review of Economic Perspectives / Národohospodářský obzor, Masaryk University, Faculty of Economics and Administration, Brno, Czech Republic. This article is an open access article distributed under the terms and conditions of the Creative Commons Attribution 3.0 license, Attribution - Non Commercial - No Derivatives. 
it. Regional disparities, as in every country, represent one of the basic problem areas in Turkey and this issue has always been addressed in the state development plans (Gezici and Hewings, 2004: 114; Lagendijk et al. 2009: 386). Although the regional policy has always been given importance in all development plans for more than 50 years, regional imbalances still exist as a major problem in Turkey. Especially, the difference between Eastern and Western regions in terms of regional development is explicit (SavaşYavuzçehre, 2016: 358) and requires the policies to eliminate or minimize those differences (Toktaş et al., 2013: 671).

Regional disparities have always been an important debate in Turkey since the establishment of the Republic in 1923. Regional policy has been on the agenda of Turkey since the First Five-Year Development Plan (1963-1967), and this can be seen from all Development Plans (DPT, 1962; 1967; 1972; 1978; 1985; 1990; 1996; 2000; 2007; Kalkınma Bakanlığı, 2013). So far, many policies have been put into practice to overcome regional disparities. Various development tools/programs have been used as basic tools to speed up regional development and to eliminate regional imbalances. The main tools are integrated regional development plans (IRDPs), investment incentives, priority development areas (PDAs) policies, organized industrial estates (OIEs), Small Industry Sites (SISs) and rural development projects (RDPs) (Özaslan et al., 2006: 3). One of the most important policy programs is state aids for investments (investment incentives) program.

In this context, the main purpose of this study is to investigate the success of the incentive system in Turkey. In the study, the regional distribution of investment incentives and the effect of investment incentive system to change the distribution of investments according to regions will be examined for the period of 2001-2016 (the latest and up to date investment incentive data at the provincial level). The "success" and the "effectiveness" of the new investment incentive scheme will be examined with a shift of investment incentives from developed regions to less developed regions and a change (an increase) in the share of less developed regions in total investment incentives. The main research questions of this paper are:

- What is the regional/spatial distribution of investment incentives during 20012016 ?

- $\quad$ Is the new investment incentive system in 2012 effective to shift investments to the less developed provinces/regions?

The method used in the study is mainly descriptive and statistical analysis of Turkish Investment Incentives Data. To analyze the spatial and regional distribution of investment incentives and the share of total investment incentives at the regional level, provincial level data was aggregated at the regional level according to Turkey's Regional Investment Incentives Scheme definition. After the aggregation process, by using investment incentives data, regional distribution of investments was revealed with the help of map-graph technique to show geographical distribution and the change of investment incentives in Turkey in the period of 2001-2016. The maps were generated both using investment amounts and investment incentive certificates.

At this point, there is a point to mention. The purpose of this study is not to reveal the effect of investment incentives on factors such as production, employment, exports and per capita GDP. The purpose of the study is to determine whether the new investment 
incentive system is effective in shifting investments from developed regions to backward regions. In addition, the factors affecting investments such as inflation, exchange rate, political (in)stability are not the subject of this study. This study does not aim to examine the factors that change of the investment incentives in the given period; it aims to examine the change of investment incentives at the regional level.

\section{Literature Review: Investment Incentives and Regional Development}

The effects of investment incentives on regional development has been discussed in various studies both theoretically and empirically for many years (Wanhill, 1986; Faini and Schiantarelli, 1987; Goolsbee, 1998; Driehuis and van den Noord, 1998; Schalk and Untiedt, 2000; Glaeser and Edward, 2001; Gabe and Kraybill, 2002; Harris and Trainor, 2005; Bondonio and Greenbaum, 2006; Porsse et al., 2007; Van Parys and James, 2010). Studies on investment incentives generally focus many aspects such as on employment (Krmenec, 1990; Bondonio, 2004; Bondonio and Greenbaum, 2006), welfare (Fehr, 1996), regional economic growth (Bondonio and Greenbaum, 2007) or technological change (Gibbs, 1984).

Incentive schemes are one of the most frequently used tools for regional development, in both developed and developing countries (For example see: Jenkins, 1982; Manasan, 1988; Amin et al., 1994; Besley, 1995; Feltenstein and Shahb, 1995; Schalk and Untiedt, 2000; Bronzini and de Blasio, 2006). Likewise, state aids and incentives have been applied in Turkey for many years in order to eliminate regional imbalances and to develop backward regions. Nevertheless, despite comprehensive incentive policies, desired results have not been achieved in the elimination of regional imbalances. Although this new incentive system has been put into practice to increase the investment in eastern provinces/regions, a development gap between eastern and western regions still exists.

There are various studies examining the effects of investment incentives in Turkey. Many of them focus on the employment effects of investment incentives (see Kaynar, 2001; Akan and Arslan, 2008). In addition, there are various studies investigating the effects of investment incentives on fixed investments, migration, regional economic growth, and regional development (Ay, 2005; Gülmez and Yalman, 2010; Şahin and Uysal, 2011; Yayar and Demir, 2012; Yavan, 2012a; 2012b; Selim et al., 2014; Dayar and Sandalc1, 2016; Recepoğlu and Değer, 2016).

Ay (2005) analyzed the effects of investment incentives on total fixed capital investments for the period of 1980-2003. In the study, to analyze the relationship between investment incentives and total fixed capital investments regression analysis was used. As a result of the regression analysis, it was found that investment incentive applications increase total fixed capital investments. According to the findings, a $1 \%$ change in investment incentives increases total fixed capital investments by $1.04 \%$.

Akan and Arslan (2008) examined the relationship between investment incentives and employment in the Southeastern Anatolia region during the 1980-2006 period. In the study, investment incentives and employment data were used and the econometric method was applied. As a result of the analysis, it is concluded that there is a linear 
relationship between incentive investments and employment in the Eastern Anatolia region.

Şahin and Uysal (2011) analyzed the changes in the regional distribution of investment subsidies in Turkey in the framework of regional development. In the study, the authors used the shift-share technique for the period of 2002-2009. As a result of the study, it was found that the share of total incentives in relatively backward regions is not sufficient, either in terms of investment or employment created in these regions. According to the authors, it is difficult to say that the incentive system is in this sense compatible with the regional development goals.

Yavan (2012) examined the impact of investment incentives on regional economic growth. In the study, regression analysis was performed using a data set covering 81 provinces. As a result of the analysis, it was concluded that the incentives have a meaningful and positive effect on regional economic growth.

Karaalp (2014) investigated the effects of both public investments and the firm-based investment incentives on the private sector employment for the period of 2002-2011. In the study, a panel data analysis was used by employing data over 10 years. As a result of the study, it was concluded that both public investments and incentive investment have a positive impact on employment.

Selim et al. (2014) examined the effect of the investment incentive certificates and fixed investments on employment using a panel regression model for the period of 2001-2012. According to analysis results, the effect on employment of the investment incentives and fixed investments is statistically significant and positive.

Dayar and Sandalci (2016) examined the impact of public investments and investment incentives on migration in the TR33 Region. In this context, population structure, urban-rural population ratio, sectoral structure, employment, public investments, investment incentives, and migration data have been analyzed by using tables. As a result of the study, it is concluded that public investments and investment incentives have limited effects removing regional migration.

Recepoğlu and Değer (2016) investigated the effects of regional investment incentives on regional economic growth in Level-2 Regions for the period of 2004-2011. As an analysis technique, panel data cointegration and causality analysis were used. As a result of the analyses, it was found that there are statistically significant and positive effects of regional investment incentives on regional economic growth in the long term.

In addition to the aforementioned studies, there are also several studies found that investment incentives have no or little effect on regional development. These studies generally have concluded that incentives are ineffective, weak or negligible effects (Ingram and Pearson, 1981; Cohen and Legeoff, 1987; Borello, 1995; Fisher and Peters, 1998; Goss and Phillips, 1999; Peters and Fisher, 2004; Ayele, 2006).

Fisher and Peters (1998) found that incentives have a very weak or negligible impact on employment. Similarly, Peters and Fisher (2004) conclude that theoretical, empirical, and practical perspectives suggest that "economic development incentives have little or no impact on firm location and investment decisions". Goss and Phillips (1999) pointed out that there was no consistent relationship between incentives and unemployment and 
the performance of local economic development. They found that while the incentives increase the economic growth in the regions with low unemployment, it does not show the same effect in the regions where unemployment is high. Ayele (2006), in her research on the effect of investment incentives on SMEs in Ethiopia, stated that incentives are a very weak policy instrument for regional development and domestic SMEs. Finally, in the study by Cohen and Legoff (1987), it was stated that none of the studies on incentives in their literature review, could reveal a clear and concrete situation about the performance of regional incentives (Yavan, 2012a: 77). There are also various studies found that investment incentives have little or no effect in Turkey (Karaçay-Çakmak and Erden, 2004; Erden and Karaçay-Çakmak, 2005; Eser, 2011).

\section{Regional Policy in Turkey and the New Investment Incentive System}

Turkey has a quite different regional structure and consists of different regions with different economic, social and cultural characteristics (Karaalp, 2014: 79). Especially there is a huge difference between Eastern and Western part of Turkey in terms of economic and social indicators such as per capita income, education, employment, unemployment, salaries etc. (Öçal and Yıldırım, 2008; Çelebioğlu and Dall'erba, 2009; Filiztekin, 2009; Y1ldırım et al., 2009). For example, according to the data of the year 2014, while the most developed province Istanbul has $\$ 19.957$ per capita GDP, Ağrı, on the other hand, has $\$ 3.880$ per capita GDP. While Turkey has an index value of 100 in terms of per capita GDP, the index value is 165 for Istanbul province and 32 for Ağr1 province in 2014. Similarly, according to the 2014 GDP data for provinces, while Istanbul produces 623 Billion Turkish Liras (TL) GDP, Bayburt has only 1.2 Billion TL GDP (TUIK, 2016). This situation is not much different at the regional level. Although the eastern half of the country constitutes 37 percent of the population, its share of GDP is only 22 percent. In contrast, the western part of the country, with 63 percent of the population, has a share of 78 percent of GDP. GDP per capita ratio is 60 for eastern Turkey and 123 for western Turkey (Reeves, 2005: 2).

\section{Figure 1. GDP per capita by Provinces (2014, US Dollar)}

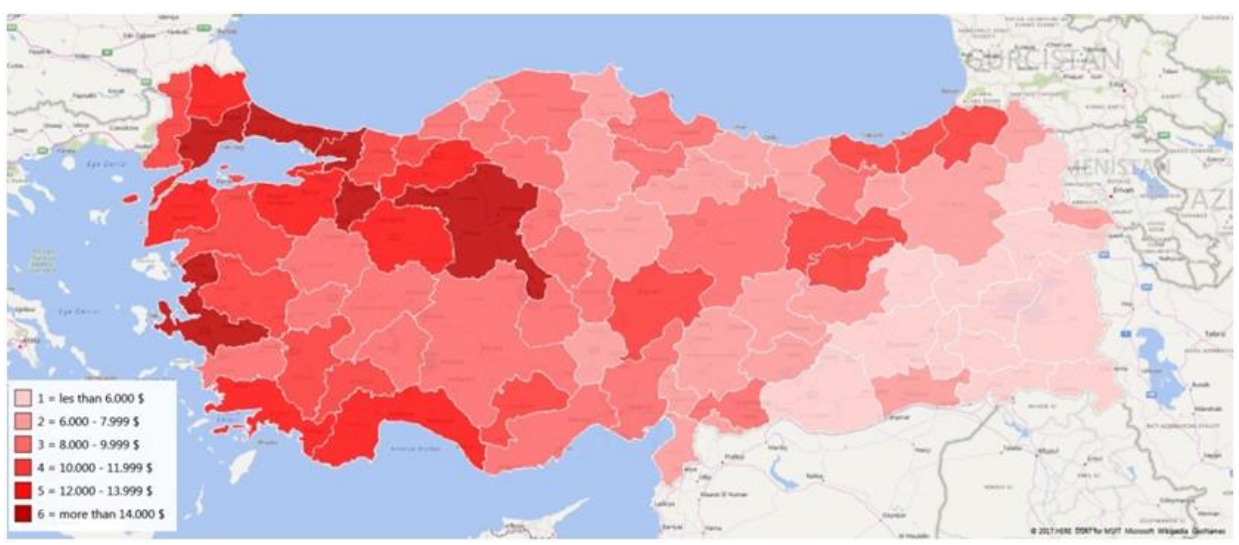

Source: Prepared by the author using the data "GDP per capita by Provinces 2004-2014" (TUIK, 2016). 
Figure 2. Well-Being Index by Provinces (2015)

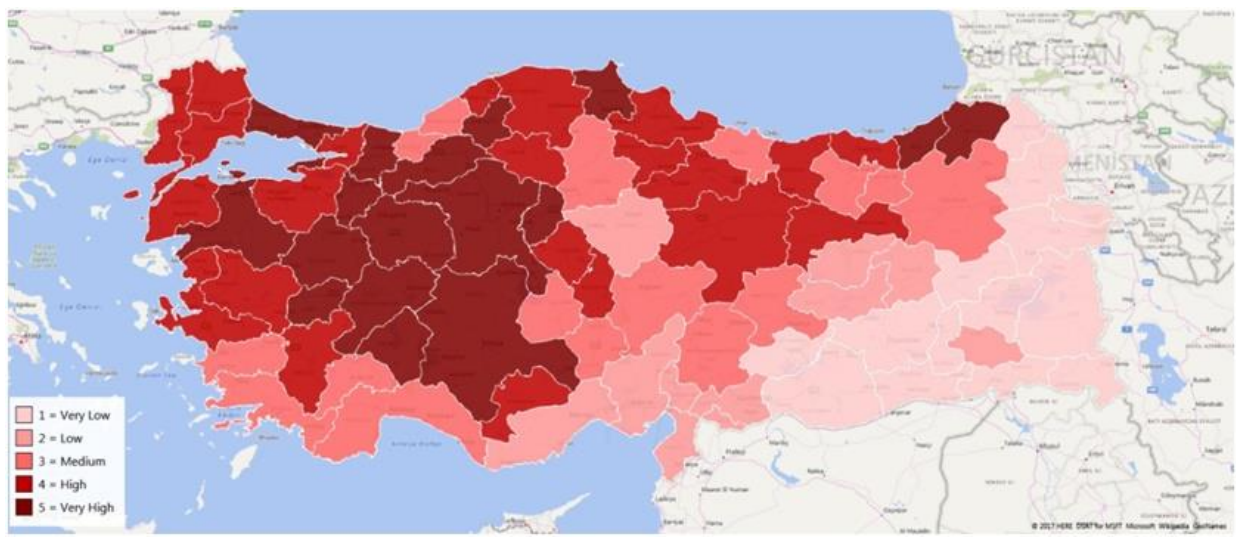

Source: Prepared by the author using Well-Being Index for Provinces Data (TUIK, 2015).

Despite the enforcement of regional development policies at different times through the history of the Turkish Republic, the economic differences between the regions have never disappeared (Turgut, 2014: 40). There are still huge differences among regions and provinces in Turkey. Especially, there is an excessive agglomeration of people and industry in the Western part of Turkey. As a result of this, the Eastern part of Turkey is much less developed than the Western part and the disparities are high between them (Önder et al., 2007) which is often called as "East-West Divide". The population, income, GDP per capita, industry, employment, and financial indicators and socioeconomic development indicators are too different between East and West. For example, Figure 1 and Figure 2 show the distribution of two main indicators, GDP per capita and socio-economic development index of provinces, using the Well-Being Index for Provinces Data (TUIK, 2015).

Because of the huge regional differences, regional policy has been an important issue since the foundation of the Republic of Turkey (Karaalp, 2014: 79). Reducing the gap between rich West and the poor East in terms of income and standard of living is an important issue in both politics and economic policymaking in Turkey. As mentioned before, various development tools/programs have been used as basic tools to speed up regional development and to eliminate regional disparities. One of the most important policy programs is state aids for investments (investment incentives) program. In addition to government investments which can be considered as external shocks to stimulate underdeveloped regions (Button, 1998), investment incentives may also be used to influence investment decisions of at a regional level (Ginevičius and Šimelytè, 2011). Investment incentives have been used to promote private investment and economic development in the least developed provinces (Aldan and Gaygisız, 2006: 1). The incentive system, which has undergone many changes until today, has been revised and updated in 2012 with the Decree No: 2012/3305.

The New Investment Incentive System of Turkey, which was introduced in April 2012, has been in force since June 15, 2012, with the Decree on "Government Subsidies for Investments" (No. 2012/3305). This Decree replaced the previous investment incentive 
scheme, which had come into force in 2009 with Decree No: 2009/15199. The procedures and principles for the implementation of the New Decree were given in detail in the Regulation no. 2012/1, which was published in the Official Gazette in July 2012 (Ministry of Economy, 2017a).

The Decree aims to steer savings into high value-added investments, to boost production and employment, to encourage large-scale and strategic investments with high R\&D content for increased international competitiveness, to increase direct foreign investments. It also aims to reduce regional development disparities and to promote investments for clustering and environment protection and for production and exportoriented growth strategy in line with the projected targets in Development Plans and Annual Programs as well as international agreements (WTO, 2015).

The new investment incentives program has four main investment incentives schemes and nine support measures. Investment Schemes are categorized as four main schemes: general, regional, large and strategic investments. The support measures provided for each incentive scheme are summarized in the Table 1 below.

Table 1. Investment Incentive Schemes and Support Measures

\begin{tabular}{lcccc} 
Support Measures & $\begin{array}{c}\text { General } \\
\text { Investment }\end{array}$ & $\begin{array}{c}\text { Regional } \\
\text { Investment }\end{array}$ & $\begin{array}{c}\text { Large Scale } \\
\text { Investment }\end{array}$ & $\begin{array}{c}\text { Strategic } \\
\text { Investment }\end{array}$ \\
\hline VAT Exemption & $\bullet$ & $\bullet$ & $\bullet$ & $\bullet$ \\
Customs Duty Exemption & $\bullet$ & $\bullet$ & $\bullet$ & $\bullet$ \\
Tax Deduction & & $\bullet$ & $\bullet$ & $\bullet$ \\
Social Security Premium Support & & $\bullet$ & $\bullet$ & $\bullet$ \\
Income Tax Withholding Support & - & $\bullet$ & $\bullet$ & $\bullet$ \\
Interest Support & & $\bullet$ & & \\
Land Allocation & & $\bullet$ & $\bullet$ & $\bullet$ \\
VAT Refund & & & -
\end{tabular}

Source: Ministry of Economy, 2014.

In the scope of General Incentive Scheme, the VAT and customs duty exemptions and income tax withholding support are available for investments regardless of region or type of investment (ÇAB, 2012). The amount of minimum fixed investment is 1 million TL in Region $1 \& 2$ and 500 thousand TL in other Regions 3, 4, 5 and 6 (See Figure 3 for Regions). The Large Scale Investment Incentive Scheme supports investment projects of different sizes in 12 industries/fields with a minimum fixed investment amount of 50 million TL. The Strategic Investment Incentive Scheme supports investment projects in all provinces of Turkey regardless of the region to increase the manufacturing of products with high import dependency (WTO, 2015). 
Figure 3. Regions Defined Under the Regional Investment Incentives Scheme

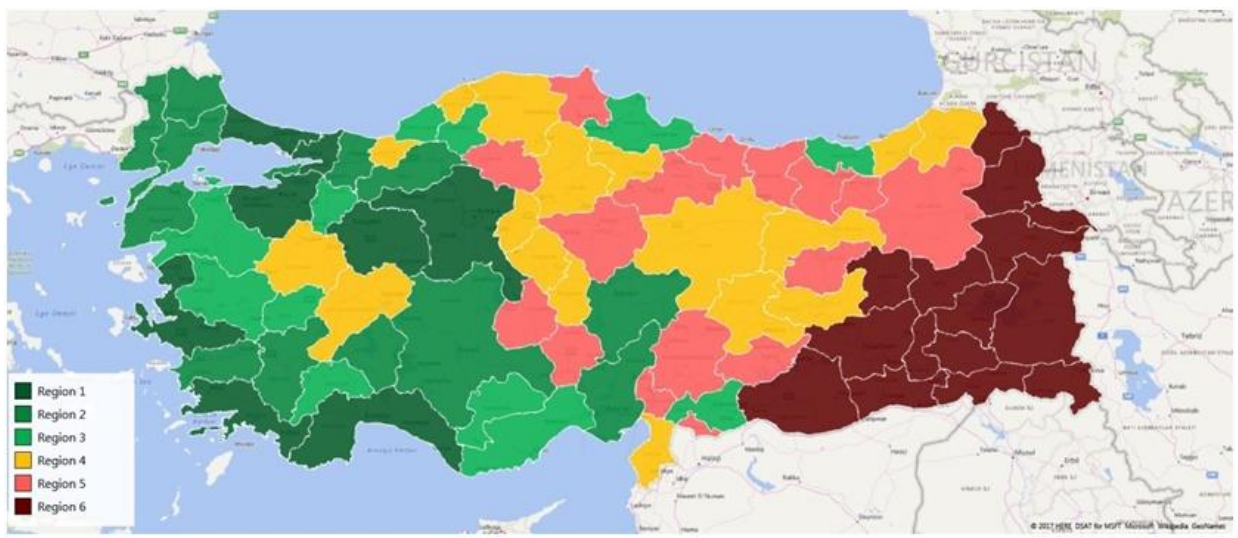

Source: Ministry of Economy, 2014.

With the new incentive system, the amount of support provided to investments in the least developed regions has been increased (T.C. Ekonomi Bakanlığ1, 2012: 7). The main difference of the new incentive system from other systems is that while incentives were not prioritized in the previous incentive systems, the new incentive system it is determined that in which sectors would receive investment support in the provinces (Kılınç Savrul and Doğru, 2013: 5). Another difference in the new incentive system is the differentiation of support rates between regions, the choice of the sector and the size of the investment (Acar ve Çağlar, 2012: 10). For example; Social Security Premium Support is implemented for 10 years in the sixth region for strategic investments and for seven years in other regions (RG, 2012: 7). Support rates and durations for regions are presented in the table below.

Table 2. Supports Rates and Durations for Regional Investments

\begin{tabular}{|c|c|c|c|c|c|c|c|}
\hline \multicolumn{2}{|l|}{ Support Measures } & Region-1 & Region-2 & Region-3 & Region-4 & Region-5 & Region-6 \\
\hline \multicolumn{2}{|l|}{ VAT Exemption } & $\checkmark$ & $\checkmark$ & $\checkmark$ & $\checkmark$ & $\checkmark$ & $\checkmark$ \\
\hline \multicolumn{2}{|c|}{ Customs Duty Exemption } & $\checkmark$ & $\checkmark$ & $\checkmark$ & $\checkmark$ & $\checkmark$ & $\checkmark$ \\
\hline \multirow{2}{*}{$\begin{array}{l}\text { Tax Deduction } \\
\text { (Investment } \\
\text { Contribution Rate) }\end{array}$} & in $\mathrm{OlZ}^{*}$ & $20 \%$ & $25 \%$ & $30 \%$ & $40 \%$ & $50 \%$ & $55 \%$ \\
\hline & out $O I Z^{*}$ & $15 \%$ & $20 \%$ & $25 \%$ & $30 \%$ & $40 \%$ & $50 \%$ \\
\hline \multirow{2}{*}{$\begin{array}{l}\text { Social Security } \\
\text { Premium Support }\end{array}$} & in $\mathrm{OlZ}^{*}$ & 3 years & 5 years & 6 years & 7 years & 10 years & 12 years \\
\hline & out $\mathrm{OIZ}^{*}$ & 2 years & 3 years & 5 years & 6 years & 7 years & 10 years \\
\hline \multicolumn{2}{|c|}{ Income Tax Withholding Support } & - & - & - & - & - & 10 years \\
\hline \multicolumn{2}{|c|}{ Interest Support (TL Credits) } & - & - & 3 points & 4 points & 5 points & 7 points \\
\hline \multicolumn{2}{|l|}{ Land Allocation } & $\checkmark$ & $\checkmark$ & $\checkmark$ & $\checkmark$ & $\checkmark$ & $\checkmark$ \\
\hline
\end{tabular}

* OIZ: Organized Industrial Zone

Source: Ministry of Economy, 2012. 
The main objective of the regional investment incentives schemes is to reduce the differences in development between the provinces by increasing their production and export potentials. For this purpose, all provinces are divided into 6 regions according to their socio-economic development levels as seen in Figure 3 (Ministry of Economy, 2014). The terms and rates of supports within the regional investment incentives scheme are differentiated in these regions. In addition, the industries to be supported through incentives in each province are determined and differentiated based on the competitive potential of the province (Ministry of Economy, 2013).

In the following table (Table 2), six different regions and the classification of provinces for each region are presented. According to this, there are eight provinces in Region 1 (the most developed provinces of Turkey), 13 provinces in Region 2, 12 provinces in Region 3, 17 provinces in Region 4 and 15 provinces in Region 5. Lastly, in Region 6, there are less developed 15 provinces of Turkey.

Table 3. Regions and Covered Provinces

\begin{tabular}{|c|c|c|c|c|c|}
\hline $1^{\text {st }}$ Region & $2^{\text {nd }}$ Region & $3^{\text {rd }}$ Region & $4^{\text {th }}$ Region & $5^{\text {th }}$ Region & $6^{\text {th }}$ Region \\
\hline Ankara & Adana & Balıkesir & Afyonkarahisar & Adıyaman & Ağrı \\
\hline Antalya & Aydın & Bilecik & Amasya & Aksaray & Ardahan \\
\hline Bursa & Bolu & Burdur & Artvin & Bayburt & Batman \\
\hline Eskişehir & Çanakkale & Gaziantep & Bartın & Çankırı & Bingöl \\
\hline İstanbul & Denizli & Karabük & Çorum & Erzurum & Bitlis \\
\hline İzmir & Edirne & Karaman & Düzce & Giresun & Diyarbakır \\
\hline Kocaeli & Isparta & Manisa & Elazığ & Gümüşhane & Hakkari \\
\hline \multirow[t]{9}{*}{ Muğla } & Kayseri & Mersin & Erzincan & Kahramanmaraş & lğdır \\
\hline & Kırklareli & Samsun & Hatay & Kilis & Kars \\
\hline & Konya & Trabzon & Kastamonu & Niğde & Mardin \\
\hline & Sakarya & Uşak & Kırıkkale & Ordu & Mus \\
\hline & Tekirdağ & Zonguldak & Kırşehir & Osmaniye & Siirt \\
\hline & Yalova & & Kütahya & Sinop & Şanlıurfa \\
\hline & & & Malatya & Tokat & Şırnak \\
\hline & & & Nevşehir & Tunceli & Van \\
\hline & & & Rize & Yozgat & \\
\hline & & & $\begin{array}{l}\text { Sivas } \\
7 \text { Provinc }\end{array}$ & & \\
\hline
\end{tabular}

Source: Ministry of Economy, 2016.

\section{Data and Methodology}

In this section of the study, the regional distribution of investment incentives is presented from 2001to 2016. Data is acquired from the Ministry of Economy, the General Directorate of Incentive Implementation and Foreign Investment (Ministry of Economy, 2017b) and regional distribution of investments is presented by map-graph using investment incentives data. The maps are generated both using investment amounts and investment incentive certificates. The data consists of both domestic and foreign investments and only includes private investments.

From 2001to 2016, 53,932 Investment Incentive Certificates were granted in Turkey, with a sum of 680,593 Million TL fixed investment. Thanks to these investments, a total 
of 2,076,072 employment opportunities have been generated in Turkey during the last 16 years (it shows the total person employed due to investments). The distribution of investment incentive certificates, investment amount and employment by provinces in Turkey is presented in the Table 3 .

Table 4. Total Investment Incentive Certificates, Investment Amount and Employment, 2001-2016

\begin{tabular}{|c|c|c|c|c|c|c|c|c|c|c|c|c|}
\hline \multirow[b]{2}{*}{ Provinces } & \multicolumn{4}{|c|}{ Number of Certificates } & \multicolumn{4}{|c|}{$\begin{array}{c}\text { Investment Amount (Millions } \\
\mathrm{TL} \text { ) }\end{array}$} & \multicolumn{4}{|c|}{ Employment (Person) } \\
\hline & $\begin{array}{l}2001- \\
04\end{array}$ & $\begin{array}{l}2005- \\
08\end{array}$ & $\begin{array}{c}2009- \\
12\end{array}$ & $\begin{array}{c}2013- \\
16\end{array}$ & $\begin{array}{c}2001- \\
04\end{array}$ & $\begin{array}{c}2005- \\
08\end{array}$ & $\begin{array}{c}2009- \\
12\end{array}$ & $\begin{array}{c}2013- \\
16\end{array}$ & $\begin{array}{c}2001- \\
04\end{array}$ & $\begin{array}{c}2005- \\
08\end{array}$ & $\begin{array}{c}2009- \\
12\end{array}$ & $\begin{array}{c}2013- \\
16\end{array}$ \\
\hline Adana & 187 & 194 & 313 & 355 & 639 & 1.414 & 21.057 & 10.209 & 19.785 & 14.685 & 10.674 & 9.804 \\
\hline Adıyaman & 30 & 51 & 107 & 207 & 223 & 303 & 1.189 & 1.461 & 1.660 & 1.869 & 2.769 & 7.106 \\
\hline Afyon & 62 & 117 & 196 & 296 & 71 & 197 & 1.485 & 2.272 & 1.892 & 2.363 & 5.388 & 4.512 \\
\hline Ağrı & 12 & 12 & 53 & 58 & 570 & 14 & 190 & 398 & 310 & 120 & 2.514 & 1.604 \\
\hline Aksaray & 28 & 65 & 96 & 208 & 129 & 228 & 1.316 & 2.735 & 1.200 & 3.249 & 4.950 & 5.345 \\
\hline Amasya & 26 & 53 & 73 & 79 & 40 & 107 & 492 & 833 & 1.416 & 1.103 & 1.848 & 1.790 \\
\hline Ankara & 535 & 504 & 532 & 865 & 2.762 & 3.386 & 4.907 & 16.280 & 23.173 & 23.748 & 20.871 & 36.352 \\
\hline Antalya & 407 & 434 & 498 & 561 & 2.801 & 3.427 & 5.847 & 10.217 & 41.778 & 32.919 & 32.408 & 32.611 \\
\hline Ardahan & 2 & 7 & 15 & 10 & 1 & 16 & 554 & 64 & 50 & 49 & 347 & 240 \\
\hline Artvin & 17 & 26 & 36 & 29 & 209 & 333 & 1.370 & 494 & 331 & 353 & 526 & 387 \\
\hline Aydın & 139 & 117 & 174 & 244 & 335 & 560 & 2.099 & 4.920 & 4.955 & 9.385 & 5.854 & 7.399 \\
\hline Balıke & 128 & 174 & 199 & 249 & 257 & 2.032 & 2.865 & 3.222 & 5.724 & 4.413 & 5.513 & 5.585 \\
\hline Bartın & 16 & 12 & 25 & 35 & 27 & 111 & 239 & 5.106 & 1.032 & 1.088 & 662 & 2.668 \\
\hline Batman & 24 & 28 & 86 & 318 & 97 & 222 & 183 & 911 & 876 & 850 & 3.839 & 25.906 \\
\hline B & 6 & 7 & 13 & 15 & 6 & 48 & 89 & 77 & 133 & 111 & 210 & 183 \\
\hline lecik & 86 & 50 & 58 & 113 & 274 & 473 & 1.552 & 820 & 6.874 & 3.073 & 3.475 & 1.879 \\
\hline BIngol & 9 & 11 & 47 & 60 & 3 & 64 & 116 & 1.425 & 232 & 192 & 1.052 & 2.848 \\
\hline this & 4 & 21 & 64 & 90 & 3 & 14 & 168 & 631 & 45 & 2 & 1.716 & 4.150 \\
\hline Bolu & 86 & 36 & 52 & 77 & 307 & 101 & 1.177 & 1.216 & 5.515 & 6.526 & 35 & 4.267 \\
\hline B & 34 & 42 & 89 & 119 & 93 & 65 & 31 & 60 & 2.054 & 1.135 & 1.347 & 1.333 \\
\hline Burs & 808 & 544 & 637 & 790 & 2.859 & 3.700 & 8.624 & 12.778 & 38.288 & 38.078 & 20.820 & 23.750 \\
\hline Çanakkale & 63 & 96 & 77 & 89 & 901 & 1.659 & 1.488 & 3.256 & 2.427 & 4.357 & 2.015 & 2.998 \\
\hline & 24 & 3 & 55 & 9 & 7 & 32 & 85 & 2.239 & 1.269 & 1. & & 4.931 \\
\hline Ç & 53 & 73 & 76 & 114 & 209 & 117 & 680 & 95 & 3.342 & 2.865 & 1.308 & 2.895 \\
\hline Deniz & 353 & 231 & 222 & 314 & 575 & 490 & 3.359 & 2.839 & 12.976 & 5.763 & 6.194 & 4.708 \\
\hline iyarbal & 70 & 75 & 233 & 390 & 184 & 196 & 872 & 1.873 & 3.430 & 1.632 & 6.353 & 15.943 \\
\hline D & 73 & 113 & 109 & 15 & 634 & 429 & 9 & $1.3^{3}$ & 5 & 6.5 & & 4.922 \\
\hline $\mathrm{E}$ & 24 & 39 & 48 & 49 & 67 & 131 & 30 & 6 & 1.889 & 8 & 96 & 1.024 \\
\hline Elaz & 47 & 60 & 138 & 139 & 75 & 233 & 1.719 & 1.322 & 1.261 & 1.989 & 2.651 & 2.128 \\
\hline Erzinca & 19 & 40 & 78 & 61 & 38 & 54 & 1.186 & 3.070 & 430 & 770 & 2.125 & 1.227 \\
\hline & 41 & 66 & 0 & & $0 ?$ & 421 & 75 & & 1.497 & & & 1.712 \\
\hline Eski & 142 & 135 & 144 & 23 & 701 & 580 & 2.323 & 4.823 & 8.337 & 5.269 & 8.193 & 5.385 \\
\hline Gaziantep & 446 & 370 & 612 & 684 & 1.829 & 1.066 & 5.794 & 8.419 & 18.782 & 11.298 & 20.578 & 15.431 \\
\hline Giresun & 17 & 49 & 83 & 101 & 36 & 245 & 585 & 700 & 404 & 705 & 2.457 & 3.552 \\
\hline Güm & 10 & 19 & 47 & 37 & 31 & 111 & 4 & & 37 & & & 451 \\
\hline ". & 8 & 12 & 22 & 3 & & 59 & 11 & 1 & 157 & 2 & 4 & 1.075 \\
\hline Hatay & 170 & 115 & 209 & 232 & 1.670 & 706 & 4.198 & 7.574 & 4.541 & 2.756 & 6.229 & 7.655 \\
\hline lğdır & 16 & 9 & 33 & 41 & 28 & 22 & 70 & 218 & 355 & 200 & 768 & 1.551 \\
\hline & 50 & 88 & 91 & 143 & 107 & 132 & 850 & 1.783 & 1.415 & 1.95 & 1.983 & 3.039 \\
\hline İsta & 2.805 & 2.012 & 1.533 & 2.003 & 10.446 & 18.352 & 33.940 & 53.965 & 98.981 & 76.575 & 65.395 & 87.533 \\
\hline İzmir & 712 & 561 & 617 & 818 & 2.767 & 2.745 & 19.213 & 10.969 & 34.399 & 17.844 & 19.368 & 26.769 \\
\hline K.mar & 148 & 202 & 216 & 416 & 707 & 1.416 & 3.472 & 5.170 & 9.234 & 10.031 & 6.429 & 8.632 \\
\hline Kare & 23 & 11 & 23 & II & 42 & 61 & 200 & 78 & 1.579 & 112 & 1.131 & 1.185 \\
\hline Karam & 3 & 52 & 88 & 123 & 311 & 162 & 705 & 2.380 & 2.917 & 2.223 & 2.813 & 3.433 \\
\hline Kars & 11 & 16 & 39 & 39 & 6 & 138 & 306 & 262 & 210 & 265 & 866 & 2.172 \\
\hline Kastamonu & 27 & 58 & 92 & 94 & 43 & 73 & 741 & 886 & 709 & 1.606 & 3.833 & 3.179 \\
\hline
\end{tabular}




\begin{tabular}{|c|c|c|c|c|c|c|c|c|c|c|c|c|}
\hline Kayseri & 216 & 171 & 285 & 424 & 814 & 711 & 2.043 & 4.391 & 11.290 & 5.737 & 9.096 & 7.285 \\
\hline Kırıkkale & 19 & 35 & 34 & 79 & 190 & 111 & 265 & 1.838 & 661 & 570 & 559 & 1.929 \\
\hline Kırklareli & 81 & 63 & 87 & 101 & 574 & 289 & 1.018 & 4.630 & 4.934 & 1.789 & 2.608 & 3.543 \\
\hline Kırşehir & 12 & 29 & 42 & 63 & 7 & 106 & 1.049 & 2.019 & 205 & 704 & 1.652 & 1.865 \\
\hline Killis & 4 & 13 & 35 & 43 & 4 & 19 & 95 & 1.110 & 78 & 211 & 557 & 1.331 \\
\hline Kocaeli & 371 & 365 & 455 & 515 & 2.557 & 3.343 & 13.223 & 15.373 & 19.393 & 20.135 & 19.407 & 17.154 \\
\hline Konya & 332 & 423 & 653 & 813 & 472 & 746 & 2.932 & 7.275 & 10.489 & 10.418 & 14.840 & 14.730 \\
\hline Kütahya & 48 & 78 & 116 & 170 & 157 & 340 & 1.009 & 2.093 & 1.469 & 2.273 & 5.302 & 5.698 \\
\hline Malatya & 98 & 96 & 186 & 161 & 238 & 159 & 1.096 & 3.177 & 5.748 & 4.984 & 8.012 & 4.517 \\
\hline Manisa & 225 & 230 & 352 & 460 & 1.226 & 1.233 & 4.695 & 9.455 & 12.989 & 11.574 & 15.336 & 16.949 \\
\hline Mardin & 37 & 58 & 175 & 231 & 132 & 82 & 1.469 & 3.388 & 495 & 1.401 & 5.751 & 13.158 \\
\hline Mersin & 201 & 243 & 285 & 418 & 581 & 872 & 2.540 & 15.223 & 4.306 & 4.228 & 6.909 & 10.588 \\
\hline Muğla & 189 & 126 & 205 & 351 & 982 & 773 & 1.901 & 4.630 & 11.392 & 5.422 & 8.799 & 9.397 \\
\hline Muş & 7 & 17 & 69 & 65 & 4 & 93 & 1.126 & 256 & 65 & 400 & 1.670 & 3.136 \\
\hline Nevşehir & 35 & 58 & 80 & 140 & 29 & 92 & 281 & 702 & 1.293 & 1.419 & 1.589 & 1.888 \\
\hline Niğde & 38 & 61 & 83 & 196 & 79 & 133 & 447 & 1.148 & 2.473 & 1.846 & 1.874 & 2.607 \\
\hline Ordu & 39 & 105 & 111 & 112 & 39 & 282 & 696 & 1.224 & 1.235 & 2.390 & 5.539 & 4.801 \\
\hline Osmaniye & 20 & 76 & 84 & 121 & 19 & 1.117 & 1.252 & 1.879 & 360 & 3.181 & 2.241 & 3.241 \\
\hline Rize & 24 & 27 & 45 & 50 & 66 & 414 & 379 & 323 & 1.406 & 468 & 947 & 908 \\
\hline Sakarya & 132 & 155 & 157 & 210 & 1.287 & 956 & 2.463 & 6.086 & 9.807 & 6.418 & 8.155 & 8.830 \\
\hline Samsun & 83 & 114 & 189 & 154 & 312 & 273 & 3.054 & 2.616 & 2.788 & 3.397 & 6.118 & 4.619 \\
\hline Siirt & 12 & 21 & 30 & 61 & 59 & 590 & 345 & 1.142 & 752 & 800 & 1.186 & 3.121 \\
\hline Sinop & 13 & 16 & 54 & 43 & 12 & 367 & 169 & 221 & 253 & 314 & 2.086 & 1.932 \\
\hline Sivas & 74 & 106 & 161 & 191 & 83 & 314 & 852 & 1.941 & 3.017 & 3.013 & 3.627 & 4.447 \\
\hline Şanlıurfa & 60 & 64 & 236 & 401 & 199 & 159 & 1.089 & 2.289 & 2.852 & 1.958 & 9.377 & 24.120 \\
\hline Şırnak & 27 & 22 & 36 & 59 & 138 & 45 & 120 & 805 & 606 & 227 & 615 & 2.551 \\
\hline Tekirdağ & 429 & 323 & 331 & 430 & 1.919 & 1.975 & 4.671 & 9.858 & 26.074 & 16.204 & 12.149 & 11.868 \\
\hline Tokat & 44 & 69 & 103 & 110 & 42 & 318 & 452 & 1.266 & 1.841 & 1.906 & 2.176 & 7.607 \\
\hline Trabzon & 65 & 108 & 132 & 114 & 92 & 367 & 1.441 & 912 & 1.829 & 1.653 & 4.115 & 2.388 \\
\hline Tunceli & 3 & 8 & 20 & 23 & 2 & 103 & 61 & 70 & 45 & 85 & 371 & 281 \\
\hline Uşak & 68 & 69 & 90 & 144 & 161 & 341 & 628 & 697 & 2.895 & 1.889 & 2.066 & 1.073 \\
\hline Van & 19 & 40 & 148 & 124 & 14 & 170 & 678 & 1.040 & 594 & 1.082 & 4.585 & 3.941 \\
\hline Yalova & 28 & 61 & 55 & 122 & 69 & 475 & 1.111 & 4.196 & 731 & 4.352 & 2.391 & 11.567 \\
\hline Yozgat & 30 & 41 & 73 & 105 & 24 & 79 & 230 & 1.090 & 1.242 & 994 & 1.145 & 3.265 \\
\hline Zonguldak & 71 & 108 & 69 & 74 & 723 & 2.808 & 554 & 2.345 & 4.212 & 5.507 & 1.591 & 2.317 \\
\hline TOTAL & 11191 & 10642 & 13612 & 18229 & 46564 & 66700 & 196420 & 310280 & 523398 & 433204 & 478292 & 611901 \\
\hline
\end{tabular}

Source: Ministry of Economy Investment Incentive Statistics, 2016.

\section{Results and Discussion}

In this section, the spatial distribution of investment incentives according to the provinces and its development through the period 2001-2016 is analyzed and presented using a map-graph technique.

The examined period (2001-2016) was divided into four equal four-year time intervals (2001-2004, 2005-2008, 2009-2012 and 2013-2016) to analyze the spatial and regional distribution of investment incentives and to show geographical distribution and the change of investment incentives in the given period. Moreover, this partition was made to show the effect of the new investment incentive system, which was introduced in April 2012 and has been in force since June 15, 2012. It is expected that the effect of a new investment incentive system to shift the investments from developed regions to less developed regions would be visible starting from the year 2013.

First, as can be seen in the Table 3, the most incentive certificates in the period of 20012016 were granted to Istanbul province with the number of 8,353 investment certificates. This is followed by Bursa with 2,779 certificates, İzmir with 2,708 certificates, Ankara 
with 2,436 certificates and Konya with 2,221 certificates. The least incentive certificates are given to Ardahan with 34 certificates, Bayburt with 41 certificates, Tunceli with 54 certificates, Hakkari with 77 certificates and Bartın with 88 certificates. Istanbul has the highest share of incentives with $15.47 \%$, while the least share belongs to Ardahan with $0.06 \%$. It can be seen that the investment incentives are concentrated in five provinces Istanbul, Bursa, İzmir, Ankara, and Konya. These provinces receive more than one-third of the total investment incentives $(34.25 \%)$ in Turkey. The first 10 provinces receive more than half of the total investment incentives $(50.3 \%)$, while the remaining 71 provinces receive the remaining share. The bottom 10 provinces -Karabük, Artvin, Kars, Iğdır, Kilis, Bartın, Hakkari, Tunceli, Bayburt, and Ardahan- receive only $1.51 \%$ of all the investment incentives certificates.

From 2001 to 2016, a total of 619,964 Million TL fixed investment has been made in the provinces thanks to the investment incentive. When four-year periods taken into consideration, the effect of the latest investment incentive program can be seen clearly. The sum of fixed investment amount is 45,564 Million TL for the period of 2001-04, 66,700 Million TL for the period of 2005-08, 196,420 Million TL for the period of 2009-12 and 310,280 Million TL for the period of 2013-16. This corresponds to an increase of 58 percent in the period of 2013-2016 compared with the previous period.

Since 2001, the province with the highest investment amount has been Istanbul with a total of 116,703 Million TL (18.8 percent). It is followed by Izmir with 35,694 Million TL, Kocaeli with 34,496 Million TL, Adana with 33,319 Million TL and Bursa with 27,961 Million TL respectively. The provinces with lowest investment amount are Ardahan with 635 Million TL, Hakkari with 344 Million TL, Iğdır with 338 Million TL, Tunceli with 236 Million TL and the last one Bayburt with 220 million TL.

The examination of the change of investment amount by provinces reveals some interesting results. Within 16 years, there has been a huge increase in the total amount of investment in some provinces such as Bingöl, Kırşehir, Kilis, Bartın, and Osmaniye. Generally, it can be seen that the investment has been increased in each province, except Ağr1. Ağr1 is the only province where investments have been decreased. In addition, total investments have been decreased in 14 provinces (Adana, Ardahan, Artvin, Bayburt, Bilecik, Denizli, Elazı̆̆g, Gümüşhane, İzmir, Kars, Muş, Rize, Samsun, and Trabzon) in the period of 2013-16 compared with the previous period 2009-12.

Figure 4 shows the distribution of investment incentive certificates by provinces for the period 2001-2016. According to this, Istanbul has the most intense color on the map hence it receives about $16 \%$ of all investment incentive certificates. In addition, it is clearly seen that the investment incentives mostly agglomerated in western and southern provinces (Bursa, Kocaeli, Izmir, Ankara, Konya, Antalya and Mersin). 
Figure 4. Distribution of Investment Incentive Certificates by Provinces (2001-2016)

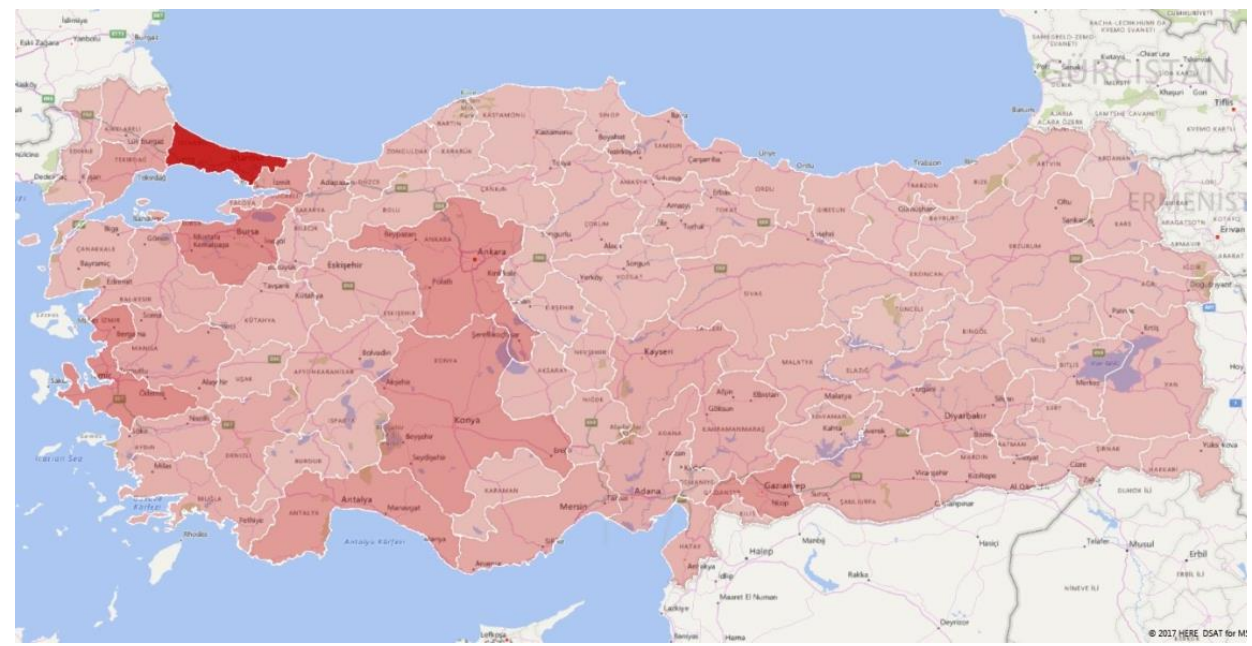

Source: Prepared by the author using Ministry of Economy Investment Incentive Statistics.

Similar results can be seen in the map showing the distribution of investment amounts by provinces in Figure 5. This map graph shows the distribution of the total amount of fixed investments between 2001 and 2016. The western provinces of Turkey have the largest share of the total investment amount as in the distribution of investment incentive certificates. These provinces are Istanbul, Bursa, Izmir, Ankara, and Konya. It is noteworthy that the concentration of investments in the Black Sea, Eastern Anatolia, and Southeastern Anatolia regions is relatively low.

\section{Figure 5. Distribution of Fixed Investment Amount by Provinces (2001-2016)}

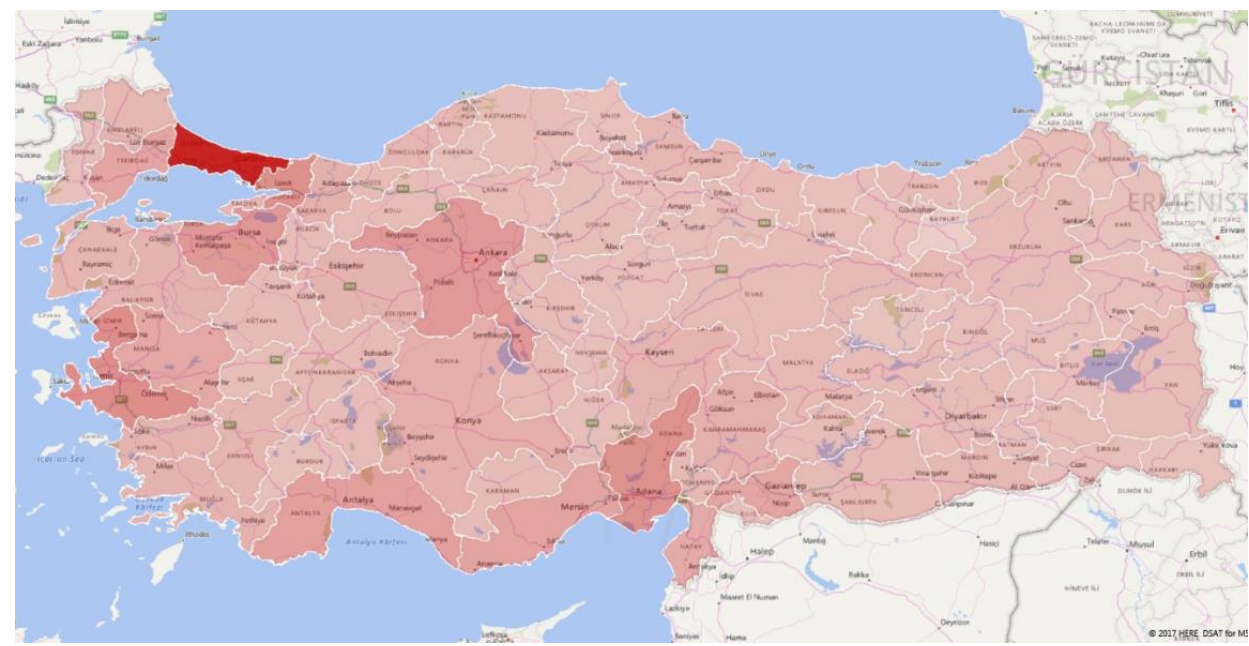

Source: Prepared by the author using Ministry of Economy Investment Incentive Statistics. 
The Figure 6 illustrates the change in the share of the investment incentive certificates of the provinces in the period 2001-2016. The red colored provinces indicate the decreasing share of the province in total investment incentive certificates, whereas green colored provinces indicate the increasing share of the province in total investment incentive certificates. According to this, although western provinces have a high share of total incentives, the share of these provinces in incentives is steadily declining. Among these provinces, İstanbul, İzmir, Kocaeli, Bursa,Ankara, and Antalya are in the Region-1, namely most developed provinces of Turkey.

Figure 6. The Change in the Share of Investment Incentive Certificates of Provinces

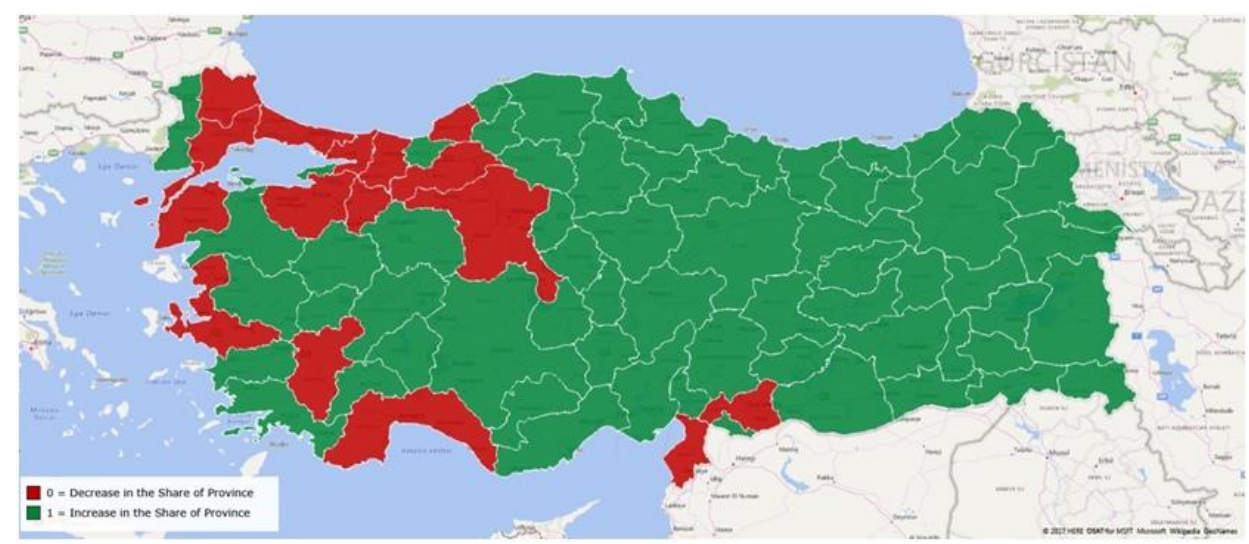

Source: Prepared by the author using Ministry of Economy Investment Incentive Statistics.

From 2001 to 2016, when the distribution of the share of investment amount of provinces is evaluated (see Figure 7), it is seen that the share of western provinces in the total investments has been gradually decreasing (red colored). The decrease in the share of Istanbul, Bursa, Kocaeli, Sakarya, Izmir, Denizli, Muğla, Antalya and Ankara is noteworthy. On the contrary, it is seen that the share of Eastern provinces in total investments is increasing, especially in the provinces such as Bitlis, Bingöl, Bayburt, Mus, Hakkari, Siirt, Tunceli, and Diyarbakır (green colored). 
Figure 7. The Change in the Share of Investment Incentive Amount of Provinces

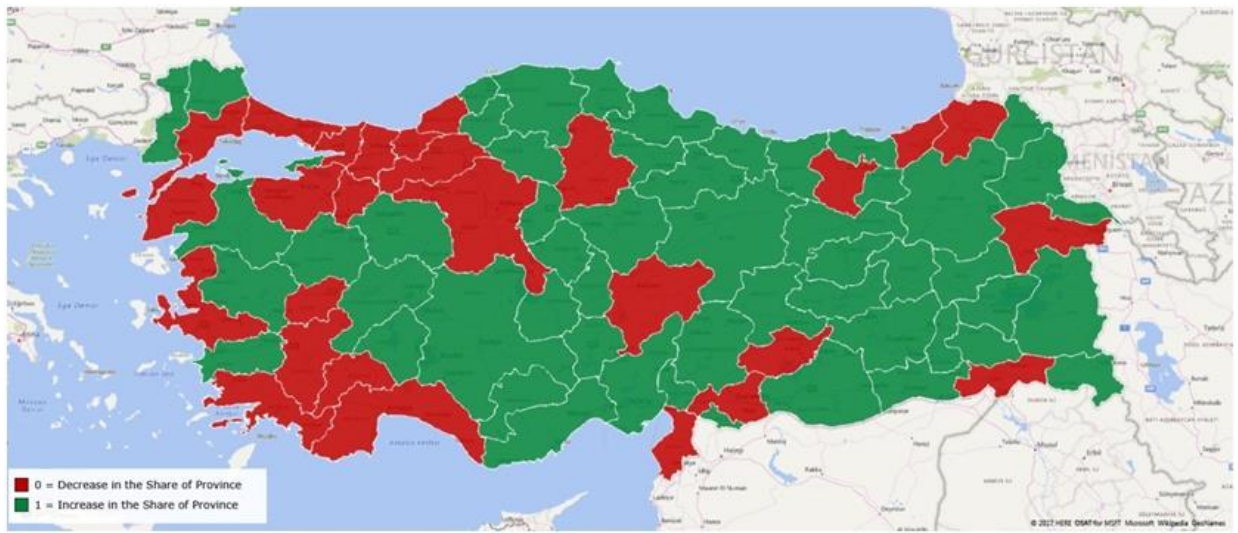

Source: Prepared by the author using Ministry of Economy Investment Incentive Statistics.

The Figure 8 shows the rate of change in the share of investment incentives of provinces. The provinces that are seen with the largest increase in the share of investment incentives are also the less developed provinces, namely Batman, Bingöl, Bitlis, Muş, Şanlıurfa, and Van. Adiyaman, Aksaray, Kilis, and Tunceli also have the largest increase in the share of investment incentives. The share of investment incentives in the aforementioned provinces has increased by more than two times (200\% or higher). It can be seen that the increase in the share of investment incentives declines from Western provinces to Eastern provinces.

Figure 8. The Rate of Change of Investment Incentive Shares of Provinces

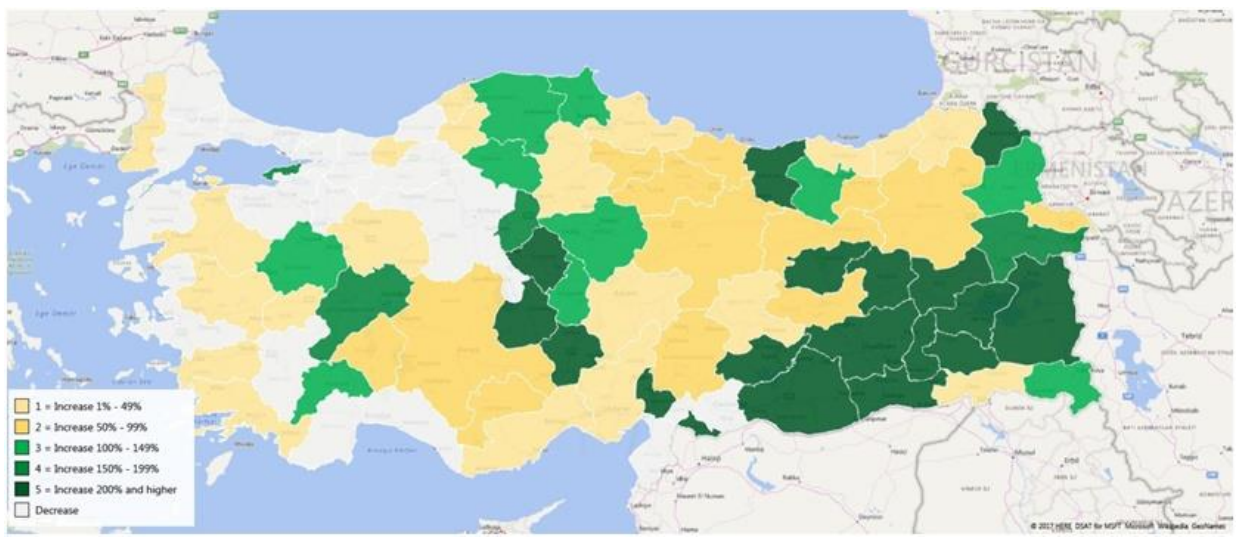

Source: Prepared by author using Ministry of Economy Investment Incentive Statistics.

The share of provinces in terms of both investment incentive certificates and the investment amount and the change in the share from 2001 to 2016 for Region- 1 and Region-6 provinces is presented in the following Table 5. According to this, while the share of Istanbul's investment incentive certificates was $24.7 \%$ in the period 2001-2004, 
it decreased to $18.8 \%$ in the period $2005-2008,11.2 \%$ in the period $2009-2012$ and lastly $10.9 \%$ in the period 2013-2016. Similarly, the share in the amount of total investment was $20.2 \%$ from 2001 to 2004 and $15.1 \%$ for the period of 2013-2016. The same decrease can be seen in the other Region-1 provinces, Antalya, Bursa, İzmir, and Kocaeli. On the other hand, it is clearly seen that the share in the investment incentives certificates has increased for all Region-6 provinces (15 provinces).

Table 5. Comparison of the Change of the Shares of Region-1 and Region-6 Provinces

\begin{tabular}{|c|c|c|c|c|c|}
\cline { 2 - 6 } \multicolumn{1}{c|}{} & \multicolumn{5}{c|}{ SHARE OF INCENTIVE CERTIFICATE } \\
\hline $\begin{array}{c}\text { Region-1 } \\
\text { Provinces }\end{array}$ & $\begin{array}{c}\mathbf{2 0 0 1 -} \\
\mathbf{0 4}\end{array}$ & $\begin{array}{c}\mathbf{2 0 0 5 -} \\
\mathbf{0 8}\end{array}$ & $\begin{array}{c}\mathbf{2 0 0 9 -} \\
\mathbf{1 2}\end{array}$ & $\begin{array}{c}\mathbf{2 0 1 3} \\
\mathbf{1 6}\end{array}$ & Change \\
\hline Ankara & 4.7 & 4.7 & 3.9 & 4.7 & \\
\hline Antalya & 3.6 & 4.1 & 3.6 & 3.1 & $\downarrow$ \\
\hline Bursa & 7.1 & 5.1 & 4.7 & 4.3 & $\downarrow$ \\
\hline Eskişehir & 1.3 & 1.3 & 1.1 & 1.3 & \\
\hline İstanbul & 24.7 & 18.8 & 11.2 & 10.9 & $\downarrow$ \\
\hline İzmir & 6.3 & 5.2 & 4.5 & 4.5 & $\downarrow$ \\
\hline Kocaeli & 3.3 & 3.4 & 3.3 & 2.8 & $\downarrow$ \\
\hline Muğla & 1.7 & 1.2 & 1.5 & 1.9 & \\
\hline TOTAL & $\mathbf{5 2 . 7}$ & $\mathbf{4 3 . 8}$ & $\mathbf{3 3 . 8}$ & $\mathbf{3 3 . 5}$ & \\
\hline
\end{tabular}

\begin{tabular}{|c|c|c|c|c|}
\hline \multicolumn{5}{|c|}{ SHARE OF INVESTMENT AMOUNT } \\
\hline $\begin{array}{c}2001- \\
04\end{array}$ & $\begin{array}{c}2005- \\
08\end{array}$ & $\begin{array}{c}2009- \\
12\end{array}$ & $\begin{array}{c}2013- \\
16\end{array}$ & Change \\
\hline 5.4 & 4.8 & 2.4 & 4.6 & 7 \\
\hline 5.4 & 4.9 & 2.9 & 2.9 & $\sqrt{7}$ \\
\hline 5.5 & 5.3 & 4.3 & 3.6 & 7 \\
\hline 1.4 & 0.8 & 1.1 & 1.4 & $=$ \\
\hline 20.2 & 26.2 & 16.8 & 15.1 & 7 \\
\hline 5.4 & 3.9 & 9.5 & 3.1 & $\sqrt{7}$ \\
\hline 5.0 & 4.8 & 6.5 & 4.3 & $\sqrt{7}$ \\
\hline 1.9 & 1.1 & 0.9 & 1.3 & $\sqrt{7}$ \\
\hline 50.2 & 51.8 & 44.4 & 36.3 & $\sqrt{7}$ \\
\hline
\end{tabular}

\begin{tabular}{|c|c|c|c|c|c|}
\hline & \multicolumn{5}{|c|}{ SHARE OF INCENTIVE CERTIFICATE } \\
\hline $\begin{array}{l}\text { Region-6 } \\
\text { Provinces }\end{array}$ & $\begin{array}{c}2001- \\
04\end{array}$ & $\begin{array}{c}2005- \\
08\end{array}$ & $\begin{array}{c}2009- \\
12\end{array}$ & $\begin{array}{c}2013- \\
16\end{array}$ & Change \\
\hline Ağrı & 0.1 & 0.1 & 0.4 & 0.3 & 1 \\
\hline Ardahan & 0.0 & 0.1 & 0.1 & 0.1 & 全 \\
\hline Batman & 0.2 & 0.3 & 0.6 & 1.7 & 令 \\
\hline Bingöl & 0.1 & 0.1 & 0.3 & 0.3 & 令 \\
\hline Bitlis & 0.0 & 0.2 & 0.5 & 0.5 & 草 \\
\hline Diyarbakır & 0.6 & 0.7 & 1.7 & 2.1 & 金 \\
\hline Hakkari & 0.1 & 0.1 & 0.2 & 0.2 & 全 \\
\hline lğdır & 0.1 & 0.1 & 0.2 & 0.2 & 全 \\
\hline Kars & 0.1 & 0.1 & 0.3 & 0.2 & 贯 \\
\hline Mardin & 0.3 & 0.5 & 1.3 & 1.3 & 会 \\
\hline Muş & 0.1 & 0.2 & 0.5 & 0.4 & 1 \\
\hline Siirt & 0.1 & 0.2 & 0.2 & 0.3 & 全 \\
\hline Şanlıurfa & 0.5 & 0.6 & 1.7 & 2.2 & 令 \\
\hline Şırnak & 0.2 & 0.2 & 0.3 & 0.3 & 全 \\
\hline Van & 0.2 & 0.4 & 1.1 & 0.7 & 全 \\
\hline TOTAL & 2.7 & 3.9 & 9.4 & 10.8 & 合 \\
\hline
\end{tabular}

SHARE OF INVESTMENT AMOUNT

\begin{tabular}{|c|c|c|c|c|}
\hline $\begin{array}{c}2001- \\
04\end{array}$ & $\begin{array}{c}2005- \\
08\end{array}$ & $\begin{array}{c}2009- \\
12\end{array}$ & $\begin{array}{c}2013- \\
16\end{array}$ & Change \\
\hline 1.1 & 0.0 & 0.1 & 0.1 & 7 \\
\hline 0.0 & 0.0 & 0.3 & 0.0 & $=$ \\
\hline 0.2 & 0.3 & 0.1 & 0.3 & 1 \\
\hline 0.0 & 0.1 & 0.1 & 0.4 & 순 \\
\hline 0.0 & 0.0 & 0.1 & 0.2 & 11 \\
\hline 0.4 & 0.3 & 0.4 & 0.5 & 1 \\
\hline 0.0 & 0.1 & 0.1 & 0.0 & $=$ \\
\hline 0.1 & 0.0 & 0.0 & 0.1 & $=$ \\
\hline 0.0 & 0.2 & 0.2 & 0.1 & 1순 \\
\hline 0.3 & 0.1 & 0.7 & 1.0 & 金 \\
\hline 0.0 & 0.1 & 0.6 & 0.1 & 1 \\
\hline 0.1 & 0.8 & 0.2 & 0.3 & 1. \\
\hline 0.4 & 0.2 & 0.5 & 0.6 & 合 \\
\hline 0.3 & 0.1 & 0.1 & 0.2 & 7 \\
\hline 0.0 & 0.2 & 0.3 & 0.3 & 金 \\
\hline 2.9 & 2.5 & 3.8 & 4.2 & 1 \\
\hline
\end{tabular}

Source: Prepared by the author using Ministry of Economy Investment Incentive Statistics. 
For example, while the share in the investment incentive certificates of Batman was $0.2 \%$ in 2001-2004, this ratio increased to $1.7 \%$ in 2013-2016. The share of the investment amount also rose from $0.3 \%$ in $2001-2004$ to $1 \%$ in $2013-2016$. The share of Diyarbakır province in the incentive certificates increased from $0.6 \%$ in the $2001-2004$ period to $2.1 \%$ in the 2013-2016 period, and the share of Mardin province increased from $0.3 \%$ in the $2001-2004$ period to $1.3 \%$ in $2013-2016$ period. The total share of these provinces in the investment incentive certificates has increased from 2.7 percent from 2001 to 2004 to 10.8 percent for the period of 2013-2016, which means four times increase.

Lastly, in the Figure 9 and Figure 10, the change of the share of Regions in terms of both investment incentive certificates and investment amount can be seen. As clearly seen in the table, while the share of Region-1 provinces has dropped seriously, the share of Region-6 provinces has been increasing. On the other hand, while the shares of Region-2 and Region-3 provinces are constant, the shares of Region-4, 5 and 6 have been increasing. According to this, it is possible to say that the new investment incentive program is effective in shifting the investments from Region-1 to Region 4-56.

Figure 9. The Distribution of Investment Incentive Certificates by Regions

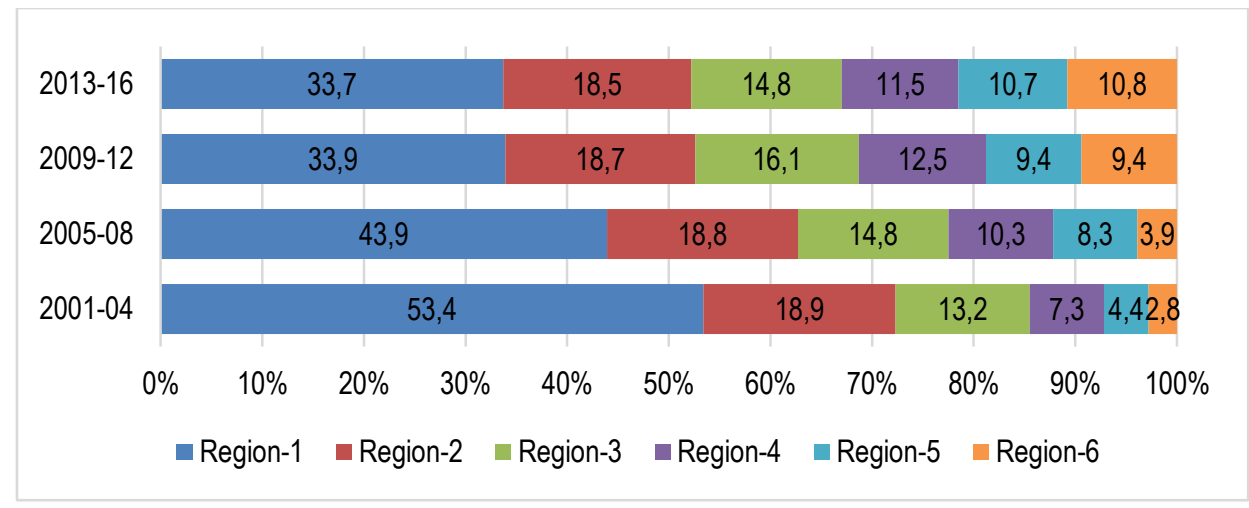

Source: Prepared by the author using Ministry of Economy Investment Incentive Statistics. 
Figure 10. The Distribution of Investment Incentive Amount by Regions

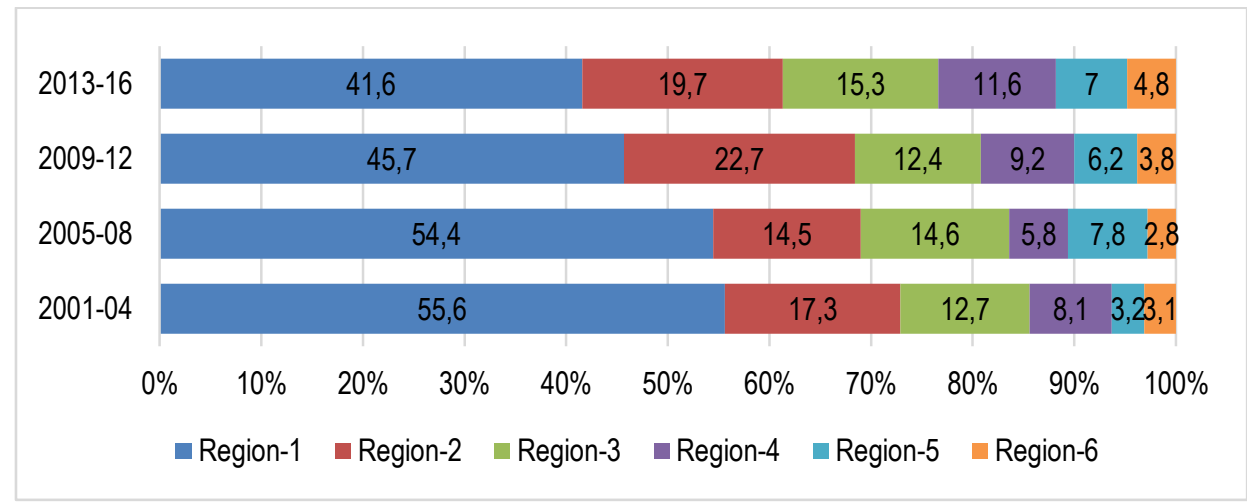

Source: Prepared by the author using Ministry of Economy Investment Incentive Statistics.

\section{Conclusion}

Although Turkey's economy has made significant progress in recent years in terms of structural transformation and integration with international markets, the regional imbalance still continues to be an important problem.

The level of development relatively decreases in general as one goes from the West to the East of the country. A general evaluation would indicate that the provinces that are in the Western part of the line connecting Zonguldak to Gaziantep are generally included in the developed provinces group. Relatively less developed provinces are located in the Eastern part of this line. Nevertheless, the development that starts in the West and extends to the periphery speeds up homogeneity tendencies throughout the country (Özaslan et al., 2006: 27-28).

As a result of this study, it is seen that both the share of investment incentive certificates and the share of the fixed investment amount in the Region-1 provinces have decreased. On the other hand, in Region-6 provinces, which include the less developed provinces, both the share of incentive certificates and the share of the investment amount have increased during the period of 2001-2016. From this point of view, it is seen that the new investment incentive system has a positive impact on increasing the share of incentives in these provinces.

In the long period, with the incentives and investments made in backward provinces/regions, the gap between the West and East has been decreasing. Of course, in addition to the new incentive system, there are various factors could affect regional disparities and could influence the increase in investment amount in less developed regions. However, the inference of the study is that the new investment incentive is seemed efficient to shift investments to the less developed regions. This finding is consistent with other studies. For example, Gerni et al. (2015) investigated the effects of investment incentives on regional convergence and they found that investment incentives eliminate the development differences by creating results that are more efficient. 
It is seen that the difference between the province where GDP per capita is highest and the province where GDP per capita is lowest is gradually decreasing in Turkey. For example, while Konya had the highest GDP per capita with 4,757 \$ and Ağrı had only 316 \$ per capita GDP in 1987, means 15 times difference between the provinces with lowest and highest per capita GDP, this figure was 10.4 times in 2001. In 2014, the province where GDP per capita is highest is Istanbul with 19,957 \$ and the provinces with the lowest GDP per capita is Ağr1 with 3,880 \$, it is seen that the difference between provinces decreased to 5.1 times (TUIK, 2015). However, this progress is not enough to overcome the main problems caused by regional disparities. There is still a need for mobilizing the private sector investment to the less developed provinces to reduce regional disparities and inter-regional migration.

The regional disparities remain as a major problem in Turkey and the investment incentives is one of the most frequently used tools in Turkey to eliminate regional imbalances. However, the effectiveness and success of the new investment incentive system have not well studied statistically and econometrically. Further research could focus on the effect of new investment incentives shifting the investments to less developed regions, using various indicators such as GDP, GDP per capita, employment, production at provincial (or regional) level with statistical/econometric models such as panel data, regression analysis, shift-share analysis etc. With these studies, whether Turkish investment inventive system is effective to decrease or to eliminate regional imbalances would be revealed and would be helpful for policymakers to formulate more effective investment incentive system in Turkey.

Disclosure statement: No potential conflict of interest was reported by the author.

\section{References}

ACAR, O., ÇAĞLAR, E. (2012). Yeni Teşvik Paketi Üzerine Bir Değerlendirme, Türkiye Ekonomi Politikaları Araştırma Vakfı (TEPAV), Ankara.

AKAN, Y., ARSLAN, İ. (2008). Türkiye'de Sektörel Yatırım Teşvik Belgeleri ile İstihdam Analizi: Doğu Anadolu Bölgesi Üzerine Bir Uygulama (1980-2006), Çalışma ve Toplum, 2008/1, 107-119.

ALDAN, A., GAYGISIZ, E. (2006) Convergence Across Provinces of Turkey: A Spatial Analysis, The Central Bank of the Republic of Turkey Research and Monetary Policy Department Working Paper No:06/09.

AMIN, A., BRADlEY, D., HOWELlS, J., TOMANEY, J., GENTLE, C. (1994). Regional Incentives and the Quality of Mobile Investment in the Less Favoured Regions of the EC, Progress in Planning, 41(1), 1-112. DOI: 10.1016/0305-9006(94)90010-8

AY, H.M. (2005). Yatırım Teşviklerinin Sabit Sermaye Yatırımları Üzerindeki Etkisi, Selçuk Üniversitesi Karaman İktisadi ve İdari Bilimler Dergisi, 2(5), 176-184.

AYELE, S. (2006). The Industry and Location Impacts of Investment Incentives on SME's Start-Up in Ethiopia, Journal of International Development, 18, 1-13. DOI: $\underline{10.1002 / j i d .1186}$ 
BESLEY, T. (1995). Property Rights and Investment Incentives: Theory and Evidence from Ghana, Journal of Political Economy, 103(5), 903-937. DOI: $10.1086 / 262008$

BONDONIO, D. (2004). Do Business Incentives Increase Employment in Declining Areas? Mean Impacts Versus Impacts by Degrees of Economic Distress, Paper presented at the XIX National Conference of Labour Economics, September 23-24th, Modena, Italy.

BONDONIO, D., GREENBAUM, R.T. (2006). Do Business Investment Incentives Promote Employment in Declining Areas? Evidence from EU Objective-2 Regions", European Urban and Regional Studies, 13(3): 225-244

BONDONIO, D., GREENBAUM, R.T. (2007). Do Local Tax Incentives Affect Economic Growth? What Mean Impacts Miss in the Analysis of Enterprise Zone Policies, Regional Science and Urban Economics, 37(1), 121-136. DOI: $\underline{10.1177 / 0969776406065432}$

BORELLO J. A. (1995). Regional development and industrial promotion in Argentina: A review of events and writings, International Journal of Urban and Regional Research, 19 (4), 576-592. DOI: 10.1111/j.1468-2427.1995.tb00529.x

BRONZINI, R., De BLASIO, G. (2006). Evaluating the Impact of Investment Incentives: The Case of Italy's Law 488/1992, Journal of Urban Economics, 60, 327 349. DOI: $10.1016 /$ j.jue.2006.03.005

BUTTON, K. (1998). Infrastructure Investment, Endogenous Growth, and Economic Convergence, Annals of Regional Science, 32(1), 145-162. DOI: $10.1007 / \mathrm{s} 001680050067$

ÇAB - Çakmak Avukatlık Bürosu (2012). New Investment Incentive Package in Turkey, 19 June.

ÇELEBIOĞLU, F., DALL'ERBA, S. (2009). Spatial Disparities Across the Regions of Turkey: An Exploratory Spatial Data Analysis, The Annals of Regional Sciences, 45(2), 379-400.

COHEN, D., LEGOFF, J-P. (1987). Regional development incentives: A critical overview of the evidence, Canadian Journal of Regional Science, 10(2), 149-167.

DAYAR, H., SANDALCI, U. (2016). Yatırım Teşviklerinin Göçler Üzerindeki Etkisi: TR33 Bölgesi, Insan ve Toplum Bilimleri Araştırmaları Dergisi, 5(7), 2041:2064. DOI: $\underline{10.15869 / i t o b i a d .259553}$

DPT (1962). Birinci Beş Yıllık Kalkınma Planı, DPT, Ankara.

DPT (1967). İkinci Beş Yıllık Kalkınma Planı, DPT, Ankara.

DPT (1972). Üçüncü Beş Yıllık Kalkınma Planı, DPT, Ankara.

DPT (1978). Dördüncü Beş Yıllık Kalkınma Planı, DPT, Ankara.

DPT (1985). Beşinci Beş Yıllık Kalkınma Planı 1985-1989, DPT, Ankara.

DPT (1990). Altıncı Beş Yıllık Kalkınma Planı 1990-1994, DPT, Ankara.

DPT (1996). Yedinci Beş Yıllık Kalkınma Planı 1996-2000, DPT, Ankara. 
DPT (2000). Uzun Vadeli Strateji ve Sekizinci Beş Yıllık Kalkınma Planı 2001-2005, Ankara.

DPT (2007), Dokuzuncu Kalkınma Planı 2007-2013, Ankara.

DRIEHUIS, W., VAN DEN NOORD, P.J. (1998). The Effects of Investment Subsidies on Employment, Economic Modelling, 5(1), 32-40. DOI: 10.1016/S02649993(98)90005-0

ERDEN, L. and KARAÇAY-ÇAKMAK, H. (2005). Türkiye'de Yerel Kalkınma ve Devletin Rolü: Bir Yöresel Panel Veri Analizi, Hacettepe University Journal of Economics and Administrative Sciences, 23(2), 13-32.

ESER, E. (2011). Türkiye'de Uygulanan Yatırım Teşvik Sistemleri ve Mevcut Sistemin Yapısına Yönelik Öneriler (SPO Publication No. 2822). Ankara: General Directorate of Economic Sectors and Coordination.

FAINI, R., SCHIANTARELLI, F. (1987). Incentives and Investment Decisions: The Effectiveness of Regional Policy, Oxford Economic Papers, 39(3) 516-533. DOI: 10.1093/oxfordjournals.oep.a041803

FEHR, H. (1996). Welfare Effects of Investment Incentive Policies: A Quantitative Assessment, Finanz Archiv / Public Finance Analysis, 53(3/4), 515-544.

FELTENSTEIN, A., SHAHB, A. (1995). General Equilibrium Effects of Investment Incentives in Mexico, Journal of Development Economics, 46(2), 253-269. DOI: $\underline{10.1016 / 0304-3878(94) 00063-\mathrm{I}}$

FILIZTEKIN, A. (2009). Regional Unemployment in Turkey, Papers in Regional Science, 88(4), 863-878. DOI: 10.1111/j.1435-5957.2009.00237.X

FISHER, P.S., PETERS, A. H. (1998). Industrial Incentives: Competition Among American States and Cities, W.E. Upjohn Institute for Employment Research, Kalamazoo.

GABE, T.M., KRAYBILL, D.S. (2002) The Effects of State Economic Development Incentives on Employment Growth of Establishments, Journal of Regional Science, 42(4), 703-730. DOI: $10.1111 / 1467-9787.00278$

GERNI, C., SARI, S., SEVİNÇ, H., EMSEN, Ö. S. (2015). Bölgesel Dengesizliklerin Giderilmesinde Yatırım Teşviklerinin Rolü ve Başarı Kriteri Olarak Yakınsama Analizleri: Türkiye Örneği, International Conference on Eurasian Economies, Eurasian Economists Association, Istanbul, Turkey, 311-320.

GEZICI, F., HEWINGS, G.J.D. (2004). Regional Convergence and the Economic Performance of Peripheral Areas in Turkey, Review of Urban \& Regional Development Studies, 16(2), 113-132. DOI: 10.1111/j.1467-940X.2004.00082.X

GIBBS, D.C. (1984). The Influence of Investment Incentives on Technological Change, Area, 16(2), 115-120.

GINEVIČIUS, R., ŠIMELYTĖ, A. (2011). Government Incentives Directed Towards Foreign Direct Investment: A Case of Central and Eastern Europe, Journal of Business Economics and Management, 12, 435-450. DOI: 10.3846/16111699.2011.599415 
GLAESER, E.L., EDWARD, L. (2001). The Economics of Location-Based Tax Incentives, Discussion Paper No: 1932, Harvard Institute of Economic Research.

GOOLSBEE, A. (1998). Investment Tax Incentives, Prices, and the Supply of Capital Goods, Quarterly Journal of Economics, 113(1), 121-148. DOI: $\underline{10.1162 / 003355398555540}$

GOSS, E.P., PHILlIPS, J. M. (1999). Do Business Tax Incentives Contribute to a Divergence in Economic Growth, Economic Development Quarterly, 13(3), 217-228. DOI: $10.1177 / 089124249901300302$

GÜLMEZ, M., NOYAN YALMAN, İ., (2010). Yatırım Teşviklerinin Bölgesel Kalkınmaya Etkileri: Sivas İli Örneği, Atatürk Üniversitesi İktisadi ve İdari Bilimler Dergisi, 24(2), 235-257.

HARRIS, R., TRAINOR, M. (2005). Capital Subsidies and Their Impact on Total Factor Productivity: Firm-level Evidence from Northern Ireland, Journal of Regional Science, 45(1), 49-74. DOI: 10.1111/j.0022-4146.2005.00364.X

INGRAM, W., PEARSON, S. (1981). The impact of investment concessions on the profitability of selected firms in Ghana, Economic Development and Cultural Change, 29(4), 831-839. DOI: $\underline{10.1086 / 451294}$

JENKINS, C.L. (1982). The Use of Investment Incentives for Tourism Projects in Developing Countries, Tourism Management, 3(2), 91-97. DOI: 10.1016/0261$\underline{5177(82) 90004-8}$

KALKINMA BAKANLIĞI (2014). Onuncu Kalkınma Planı (2014-2018), Ankara.

KARAALP, H.S. (2014). The Effect of Public Investment and Firm-Based Investment Incentives on Employment: A Panel Data Analysis for Turkey, Journal of Economic and Social Development, 1(1), 74-85.

KARAÇAY-ÇAKMAK, H. and ERDEN, L. (2004). Yeni Bölgesel Kalkınma Yaklaşımları ve Kamu Destekleme Politikaları: Türkiye'den Bölgesel Panel Veri Setiyle Ampirik Bir Analiz, Gazi Üniversitesi Iktisadi ve Idari Bilimler Fakültesi Dergisi, 6(3), 77-96.

KAYNAR, N. (2001). Teşvik Belgeli Yatırımlarda Sabit Yatırım-İstihdam İlişkisi (1999-2000), DPT Yayınları, Ankara.

KILINÇ SAVRUL, B., DOĞRU, B. (2013). TR 22 Düzey 2 Bölgesinin 2012 Yılı Teşvik Sistemi Çerçevesinde Değerlendirilmesi, Çankırı Karatekin Üniversitesi İktisadi ve İdari Bilimler Fakültesi Dergisi, 3(1), 1-20.

KRMENEC, A.J. (1990). The Employment Impacts of an Investment Incentive: Differential Efficiency of the Industrial Revenue Bond, Regional Studies, 24(2), 95-107. DOI: $10.1080 / 00343409012331345824$

LAGENDIJK, A., KARAYU, S., YASAR, S. (2009). The Role of Regional Development Agencies in Turkey: From Implementing EU Directives to Supporting Regional Business Communities?, European Urban and Regional Studies, 16(4), 383396. DOI: $10.1177 / 0969776409102188$ 
MANASAN, R.G. (1988). A Review of Investment Incentives in ASEAN Countries, Working Paper No: 8827, Manila: PIDS.

MINISTRY OF ECONOMY (2012). Yeni Teşvik Sistemi, Yatırımlarda Devlet Yardımları, https://www.ticaret.gov.tr/, Ankara.

MINISTRY OF ECONOMY (2013). Yatırım Teşvik Sistemi Yıllık Değerlendirme Raporu, Teftiş Uygulama ve Yabancı Sermaye Genel Müdürlüğü, Ankara.

MINISTRY OF ECONOMY (2014). The Investment Incentive Program of Turkey, Leaflets for Turkey's New Investment Incentive System, Ankara.

MINISTRY OF ECONOMY (2016). The Framework of New Investment Incentives Program in Turkey, Ankara.

MINISTRY OF ECONOMY (2017a). Investment Incentives, URL: https://goo.gl/ITwVIS (Accessed: 25.03.2017)

MINISTRY OF ECONOMY (2017b). Investment Statistics, General Directorate of Incentive Implementation and Foreign Investment.

OCAL, N., YILDIRIM, J. (2008). Employment Performances of Turkish Provinces: A Spatial Data Analysis, Iktisat, Isletme ve Finans, 23(5), 5-10.

ÖNDER, A.Ö., KARADAĞ, M., DELIKTAŞ, E. (2007). The Effects of Public Capital on Regional Convergence in Turkey, Ege University Working Papers in Economics 2007, No: 07/01.

ÖZASLAN, M., DINÇER, B., ÖZGÜR, H. (2006). Regional Disparities and Territorial Indicators in Turkey: Socio-Economic Development Index (SEDI), paper presented at the 46th ERSA Congress, Enlargement, Southern Europe and the Mediterranean, 30 August - 3 September, Volos, Greece.

PETERS, A. and FISHER, P. (2004). The Failures of Economic Development Incentives, Journal of American Planning Association, 70(1), 27-37. DOI: $\underline{10.1080 / 01944360408976336}$

PORSSE, A., HADDAD, E., RIBEIRO, E. P. (2007). Economic Effects of Regional Tax Incentives: A General Equilibrium Approach, Latin American Business Review, 7(3-4), 195-216. DOI: 10.1300/J140v07n03 09

RECEPOĞLU, M., DEĞER, M.K. (2016). Türkiye'de Bölgesel Yatırım Teşviklerinin Bölgesel Ekonomik Büyüme Üzerine Etkisi: Düzey 2 Bölgeleri Üzerine Panel Veri Analizleri (2004-2011), Kastamonu Üniversitesi İktisadi ve İdari Bilimler Fakültesi Dergisi, 14, 6-21.

REEVES, T. (2005). Turkey's Regional Policy on the Road to the EU, Turkish Policy Quarterly, 4, 49-61.

RESMI GAZETE (RG) (2012). Bakanlar Kurulu Karar1, Karar Sayısı : 2012/3305, No: 28328, pp: 1-11.

SAHIN, M., UYSAL, E. (2011). Bölgesel Kalkınma Çerçevesinde Yatırım Teşviklerinin Shift-Share Analizi, Maliye Dergisi, 160, 111-138. 
SAVAŞ-YAVUZÇEHRE, P. (2016). A Comparative Analysis Of The Regional Development Agencies In Europe And Turkey, European Scientific Journal, May, Special Edition, 357-370.

SCHALK, H.J., UNTIEDT, G. (2000). Regional Investment Incentives in Germany: Impacts on Factor Demand and Growth, The Annals of Regional Science, 34(2), 173195. DOI: $10.1007 / \mathrm{s} 001689900008$

SELIM, S., KOÇTÜRK, O.M., ERYİĞİT, P. (2014). Türkiye'de Yatırım Teşvikleri ve Sabit Yatırımların İstihdam Üzerine Etkisi: Panel Veri Analizi, Ege Akademik Bakış Dergisi, 14(4), 661-673.

SUNGUR, O., KESKIN, H., DULUPÇU, M.A. (2013). Adaptation of Turkey's Regional Policies to the EU Acquis: An Evaluation through Progress Reports (1998 2012), Marmara Journal of European Studies, 21(2): 165-193.

TOKTAS, Y. SEVINC, H., BOZKURT, E. (2013). The Evolution of Regional Development Agencies: Turkey Case, Annales Universitatis Apulensis Series Oeconomica, 15(2), 670-681.

TUIK (2015). Well-Being Index for Provinces, Ankara.

TUIK (2016). Gross Domestic Product by Provinces by Kind of Economic Activity, NACE Rev.2, 2004-2014.

TUIK (2016). Gross Domestic Product Per Capita by Provinces, 2004-2014, Ankara.

TURGUT, M.B. (2014). Regional Economic Activity in Turkey: A New Economic Geography Approach, Ekonomik Yaklasim, 25(93), 39-63. DOI: 10.5455/ey.35516

VAN PARYS, S., JAMES, S. (2010). The Effectiveness of Tax İncentives in Attracting Investment: Panel Data Evidence from the CFA Franc Zone, International Tax Public Finance, 17, 400-429. DOI: 10.1007/s10797-010-9140-1

WANHILL, R.C. (1986). Which Investment Incentives for Tourism?, Tourism Management, 7(1), 2-7. DOI: 10.1016/0261-5177(86)90052-X

WTO (2015). "Subsidies - New and Full Notification Pursuant to Article XVI:1 of the GATT 1994 and Article 25 of the Agreement on Subsidies and Countervailing Measures, Committee on Subsidies and Countervailing Measures, G/SCM/N/253/TUR/Suppl.2.

YAVAN, N. (2012a). Teşviklerin Bölgesel Ekonomik Büyüme Üzerindeki Etkisi: Ampirik Bir Analiz, Ekonomik Yaklaşım, 81(22), 65-104.

YAVAN, N. (2012b). Türkiye'de Yatırım Teşviklerinin Bölgesel Belirleyicileri: Mekânsal ve İstatistiksel Bir Analiz, Coğrafi Bilimler Dergisi, 10(1), 9-37.

YAYAR, R., DEMIR, Y. (2012). Bölgesel Kalkınma ve Yatırım Teşvikleri: Tokat İlinde Bir Uygulama, Erciyes Üniversitesi İktisadi ve İdari Bilimler Fakültesi Dergisi, 39, 119-146. 